\title{
Constructing Ideology through Modality in Newspaper Editorials on Security Challenges in Nigeria
}

\author{
Bukola Alfred (Ile-Ife)
}

\begin{abstract}
This paper explores Nigerian media's deployment of modality on editorials on security challenges in Nigeria. The study examines how such impress on the ideological position of the media on the security issues in Nigeria. The study relates to how well Nigerian newspaper organisations attempted to reveal or mask security cases across different regions of the country through modal options. The editorials were sourced from The Punch and The Guardian (SouthWestern region), Vanguard and The Sun (East) and Leadership and Daily Trust (Northern Region) between 2014 and 2016. The frequencies and percentages of occurrences of these modality markers were examined and their implications were interpreted to reflect the attitudes and dispositions of the newspapers to security issues. Our findings show that the six newspapers expressed unbiased concerns over the Boko-Haram Insurgency whether or not the newspaper is situated in the northern region. However, the fact that certain security issues emanated from particular regions also prompted the kinds of modal markers employed by specific newspapers representing such regions. The Sun's choices of modal indirectly expressed support for their plights and protests of the pro-Biafra agitators. The Punch's choices of modal verbs portrayed President Buhari as sharing some ethnic affinity with herders.
\end{abstract}

\section{$1 \quad$ Introduction}

Language is an indispensable tool for driving person-to-person interactions and sharing attitudes, ideologies, expressing commitments, making and refuting claims and establishing human relationships. Language has strong potential to influence people and redirect human perspectives to issues. Modality is a major linguistic tool used to achieve such persuasive goals. Critically examining the effects of certain linguistic choices on the message being communicated, it is obvious that not all elements of the clause structure bear the same persuasive weight. The verbal group is meticulously chosen to bear the ideological underpinnings of a communicator. It is against this backdrop that this paper explores the modality markers used to perform ideological/manipulative roles on the readers of editorials on security challenges in Nigerian newspapers. Since 1999, Nigeria has been grappling with several degrees of security challenges based on political, religious, ethnic and regional divides among other things. Most common among the security challenges are election violence, BokoHaram insurgency, kidnappings, inter-communal crises and Niger-Delta militancy and 
recently, farmer-herders crises (which resulted from land use among farmers and nomadic herdsmen in Nigeria. This paper only focuses on four major security challenges currently ravaging the nation (Boko-Haram insurgency, Niger-Delta militancy, farmers-herdsmen clashes and inter-communal crises.

Boko-Haram (Western education is sacrilege) was founded in Maiduguri, Borno State, Nigeria, in 2002 as a Jihadist group with the initial intention of fighting corruption and injustice in Nigeria. The belief of the group was that the anomalies in the Nigerian political system can be blamed on westernisation. The group at that time was also clamouring for a change in government as they believed that democratic rulership is alien to Sharia. By 2009, the group had spread to other Northern states (such as Bauchi, Yobe, Adamawa, Gombe and Taraba) the Boko-Haram insurgents started to employ more forceful such as bombing, mass-killings, abductions and executions of hostages. For instance, Nigerians witnessed the abduction of over 200 at a Chibok school, by Boko Haram sect, from their hostels on the 14th of April 2014, and even though some of these girls were released in 2016, the whereabouts of quite a number of these girl is still misty.

In the same vein, reports on attacks of herders on villages have increased especially between 2014 and 2016. The conflict between farmers and herders is often associated to climatic change and access to land. The deteriorating environmental/climatic changes often force the nomadic herders to move (and sometimes travel) with their cattle in search of water and greener pastures. In the process of doing this farmlands and crops are usually invaded and destroyed leading to clashes between both land users. Most times, such clashes graduate into the killings of villagers. For instance, on the night of February 16 2016, Agatu community in Benue state, Nigeria, witnessed the massacre of hundreds of its villagers ( including women, children and the elderly) by the nomadic herders in revenge of the killing of one of their leaders by the Agatu people sometimes in 2013 (cf. Djadi 2016). Also, 40 people were reportedly killed at Nimbo in UzoUwani Local Government Area of Enugu State, Nigeria by no fewer than 500 heavily armed herders (cf. Vanguard 2016).

The spate of the news of militancy (in the oil producing areas of the country) and intercommunal crises are reported and commented on in Nigerian newspapers. Militancy in the Niger-Delta region has been attributed to marginalisation, environmental degradation and underdevelopment in the region (cf. Ebienfa 2011). The oil-rich Niger-Delta region has therefore resolve to pipeline vandalism, and the abduction and, sometime, execution of foreign employees of international oil companies. Between 2006 and 2011, about 200 foreign employees of international oil companies had been abducted. These security challenges in Nigeria have destroyed countless lives and properties, displaced several families, paralysed educational and socio-economic activities and increased the numbers of Internally Displaced Persons' Camps (IDPs) in several parts of the country

The grave consequences of these menaces have prompted Nigerian newspaper organisations to express their feelings and suggest solutions through a subgenre of their writings - the editorials. This research is thus necessitated by the need to examine how the modality system is used in constructing ideology on the nation's security challenges. Earlier studies on modality have largely concentrated on academic writings (Gabrielatos/McEnery 2005; Vold 2006; 
Vazquez/Giner 2008; Lillian 2008; Someya 2010; Qun 2010; Olaniyan/Adeniji 2015) and other genres of discourse such as media (Bonyadi 2011; Puteri 2013; Khalid 2013), literary (Aboh 2012) and political discourse (Boicu 2007). Not many studies have examined modality in security discourse especially in relation to security threats in Nigeria. This research is thus motivated by the dearth of study on modality in security discourse. Specifically, the paper investigates the role modality plays in constructing ideological positions on security issues in Nigeria. Although the study is hinged on Systemic Functional Linguistics, it draws some insight from critical discourse analysis. The study focused on the ideological implications of the two main modality types (epistemic and deontic) on the editorials

\section{$2 \quad$ Editorial Writings}

A newspaper editorial is a subgenre of news discourse that relates the majority or unanimous opinion of a media organisation, through its editorial board, on an issue of national significance. Editorials evaluate what has already been reported in newspapers, and they comment on such by adding facts, in a bid to proffer solutions where necessary. Ogunwale (2008: 22f.) defines an editorial as a presentation of fact and opinion in concise, logical, pleasing order for the sake of entertaining, of influencing opinions, or of interpreting significant news in such a way that its importance to the average reader will be clear.

Newspaper editorials are usually devoid of the singular personal pronoun $I$ (although sometimes there could be minimal occurrences of a plural personal pronoun we) but are usually dotted with subjective markers to reflect the sentiments of the newspaper. The overriding intention of this kind of writing is to persuade or lure readers towards seeing things from the writers' perspectives. Modality helps to achieve one of the editorial's primary intention which is to convey communicators' involvement in the propositional content of a given statement or piece of writing. Modality is a relevant concept in grammar which stems from the interpersonal function of Halliday and Mathiessen's (2004) Introduction to Functional Grammar.

\section{$3 \quad$ Modality and Text}

Bonyadi (2011: 2f). opines that logicians relate modality to the extent of truth in a statement or state of affairs. Modality relates to the ranges of indeterminacy that lie between two extreme poles - "yes" or "no" (cf. Hallida/Mathiessen 2014: 291; Wang 2010: 256). In between these two poles are different levels of certainties or uncertainties conveyed by a communicator towards a proposition. In a situation where an individual chooses to neither affirm nor disprove a proposition, the modality scale plays a major subjective role. Halliday/Mathiessen (2014: 147f.) elucidate this assertion in their submission: "In between the certainties of 'it is' and 'it isn't' lie the relative probabilities of 'it must be', 'it will be', 'it may be'. Similarly, in between the definitive 'do!' and 'don't!' lie the discretionary options 'you must do', 'you should do', "you may do"'.

Thus, modality is characterised to convey speaker's or writer's involvement in the propositional content of a given utterance/piece of writing. Halliday (1970: 349f.) defines modality as "the speaker's assessment of probability and predictability. It is external to the content, being part of the attitude taken up by the speaker". This means that the presence of modality markers in a statement do not give any additional meaning to it, rather, it only shows the interlocutor's 
stance(s) on that statement. On this note, it can be said that modality is linked with Hyland's (2005) "metadiscourse".

Modality expresses communicator's or subject's stand-point on an issue, hence, the link between mood and modality. Bonyadi (2011: 2f.) says modality is "basically the writer's point of view, 'angle of vision', 'angle of telling', or authorial interest that determines the essence of a story's style and that provides the story with its particular feel' and 'color'. Palmer (1986: 14) sees modality as that linguistic tool that describes the speaker's attitude or opinion regarding "the contents of the sentence". McCabe/Heilman (2007: 139-148) view modality as one of the grammatical tools used to signal authorial presence. Fowler (1986: 131f.) explains that modality is "the grammar of explicit comment, the means by which people express their degree of commitment to the truth of the propositions they utter, and their views on the desirability or otherwise of the status of affairs referred".

These series of definitions have couched modality as the extent of conviction, possibility or probability that a speaker or writer has on what is said/written concerning the content of a text. Modality is a subjective way of using language to express a communicator's opinion or attitude towards issues, situations, etc. According to Halliday/Mathiessen (2014: 147f.), an interlocutor may express modality along the perspectives of "proposition" and "proposal". Proposition relates to the extent of probability, possibility or certainly as well as usuality. Proposal, on the other hand, relates to the weight placed on a speaker's comment to either make it read as an obligation or a mere disposition.

There are two ranges of modality, namely: epistemic and deontic modalities. Epistemic modality refers to the means or extent of truthfulness, credibility and conviction that a communicator has in a piece of information (experiences, statements) being passed across either through spoken or written forms (Palmer 2003: 7f.). Downing/Locke (2006: 381f.) propose that extrinsic (epistemic) modality signals "the three degrees of confidence or lack of it, that the speaker feels towards the factuality of the proposition expressed". First, a communicator tries to relate the 'factuality' or otherwise of a proposition. Sweetser (1990) points out that the epistemic (extrinsic) modality stems out of deontic (intrinsic) modality. Deontic modality, on the other hand, relates to the "expression of the judgment of possibility including permissibility or necessity including obligation of an action, state, or event by a speaker" (Palmer 2003: 7f.). Modality markers, in this class, express other meanings aside the ones in epistemic modality. Such meanings are permissibility, ability, expectations, advisability, desirability, etc. It "pertains to the use of language to express desires, wants, commands, obligations, undertaking and permission" (Olaniyan/Adeniji 2015: 45f.). Halliday (1970: 335f.) points out that the deontic modality can be viewed as "a form of participation of the speaker in the speech event." Deontic modality plays a significant role in the interpersonal process of negotiation of meaning and pertains to the use of language in expressing desires, wants, commands, obligations, undertaking and permission.

\subsection{Linguistic Manifestations of Modality within a Clause Structure}

For this study, Downing/Locke's (2006) approach to modality is adopted; the linguistic realisations, as provided by the duo, are presented below: 
(1) The lexical modal auxiliaries which usually entails another element (be/have+lexical) + toinfinitive e. g. be likely to, have got to

(2) The semi-modals need and dare

(3) Lexical verbs e. g. suggest, guarantee

(4) The verb conveying non-factual meaning e. g. wonder, wish

(5) Modal adverbs e. g. possibly, certainly, probably

(6) Modal adjectives e. g. possible, likely

(7) Modal nouns e. g. chance, likelihood

(8) Parentheticals e. g. I think, I guess

(9) The use of the past tense to indicate remoteness from reality as in I thought you'd love to eat now, if you are not reading.

\subsection{Modality, Linguistic Commitment and Editorials}

Fowler (1986: 76f.) explains that language affords us the opportunity to convey our attitude towards everything we say. Bonyadi (2011: 1f.) explains that modality plays a key role in newspaper editorial as "editorial writers tend to make use of this property to establish either a favourable or unfavourable bias throughout the text to manipulate their readers' opinion". News editorials are commonly devoid of explicit authorial presence (especially, first and second person pronouns) because such writings are expected to be objective. However, there are traces of authorial subjectivity in these writings. Since editorials are usually opinionated, a number of modal expressions would be employed to achieve the intended purposes. Mostly, the overriding intentions of editorials are to criticise supposedly ill-actions, vices and decisions and proffer solutions to them. Also, editorials may be used to persuade the readers to take specific, positive actions. A study of modality in newspaper editorials is important because it helps to signal the interpersonal meaning of the text. It is against this background that analysis will investigate the modality markers commonly employed in editorials on insecurity and what roles such serve in relating the messages of these kinds of writings.

\section{$4 \quad$ Methodology}

The corpus for this study comprises sixty (60) editorials in six Nigerian newspapers namely: The Guardian and The Punch (South-Western Nigeria); The Vanguard and The Sun (Eastern Nigeria); and Leadership and Daily Trust (Northern Nigeria). The newspapers were purposively selected on the bases of readership and representation across the country. The period of study is between 2014 and 2016. The Punch is a daily newspaper published in Lagos, Nigeria by Wale Aboderin. It has an estimated circulation of 85,000 sold copies daily. The Guardian is also published in Lagos, Nigeria. Vanguard is a newspaper published in Lagos, Nigeria, but is perceived to represent the interest of south-east Nigeria. It has an estimated circulation of 135,000 sold copies daily. The newspaper claims to serve the people with unflinching commitment to the rule of law and good governance and devoid of political control. The Sun is also published in Lagos and is owned by the former Abia state governor, Dr. Orji Uzor Kalu. It has an estimated circulation printout of 140,000 per day. Daily Trust is a national daily published in Abuja, the capital of Nigeria. Leadership is also a national daily published in Northern Nigeria, Abuja, the capital of Nigeria. It has an estimated circulation of 50,000 sold copies daily. The choices of these newspapers are based on the assumption that the Nigerian 
newspaper organisations would attempt to sentimentally present their opinions on the security issues in the different regions of the country through modal options

\section{$5 \quad$ Analysis of Modality in the Editorials}

From the analysis, it was observed that modal auxiliaries constituted the highest modality markers employed in the editorials on security challenges with a total of $56.3 \%$. These auxiliary modals were used to mark the assertiveness or tentativeness of the editorials to issues as well as their commitments to, or detachments from, claims in the editorial contents. While shall had the least appearance in this category (appearing just once), should (not) had the highest occurrence, with a percentage of $20.2 \%$, followed by must (not) and would (not) with percentages of $8.7 \%$ and $7.5 \%$, respectively. Can (not), will (not) and could (not) had percentages of $7.0 \%, 4.9 \%$ and $4.0 \%$, respectively, while may (not) had a percentage of $2.8 \%$. Ought (not) to had a percentage of $0.4 \%$ and was sparingly used in the editorials while might not had a percentage of $0.7 \%$. The modal adverb had the highest occurrence with a percentage of $14.5 \%$ and was followed by modal lexical verb, with a percentage of $9.6 \%$. The print media were more predisposed to the use of the modal adverbs and modal lexical verbs because these were effective tools for stating stances and various degrees of convictions or credibility towards certain propositions relating to security challenges. Modal determiners, modal adjectives and modal nouns had percentages of $7.8 \%, 3.5 \%$ and $5.1 \%$, respectively. Lexical modal verbs appeared with a percentage of $1.2 \%$ while semi-modals had a percentage of $2.0 \%$. All these occurrences are illustrated in the table below.

\begin{tabular}{|l|l|c|c|c|c|c|c|c|c|}
\hline Modality markers & & LNEs & VEs & TGEs & TPEs & TSEs & DTEs & Total & $\%$ \\
\hline \multirow{5}{*}{ Modal auxiliaries } & Might (not) & 2 & 1 & 1 & 2 & 0 & 0 & 6 & 0.7 \\
\cline { 2 - 12 } & May (not) & 6 & 4 & 8 & 2 & 1 & 5 & 26 & 2.8 \\
\cline { 2 - 12 } & Can (not) & 6 & 14 & 11 & 16 & 8 & 9 & 64 & 7.0 \\
\cline { 2 - 11 } & Could (not) & 3 & 2 & 5 & 13 & 3 & 10 & 36 & 4.0 \\
\cline { 2 - 11 } & Must (not) & 17 & 14 & 22 & 8 & 12 & 7 & 80 & 8.7 \\
\cline { 2 - 11 } & Shall (not) & 0 & 0 & 0 & 0 & 0 & 1 & 1 & 0.1 \\
\cline { 2 - 10 } & Should (not) & 19 & 12 & 55 & 38 & 28 & 33 & 185 & 20.2 \\
\cline { 2 - 10 } & Will (not) & 7 & 5 & 6 & 14 & 8 & 5 & 45 & 4.9 \\
\cline { 2 - 10 } & Would (not) & 9 & 9 & 18 & 9 & 11 & 13 & 69 & 7.5 \\
\cline { 2 - 10 } & Ought (not) to & 0 & 0 & 2 & 0 & 2 & 0 & 4 & 0.4 \\
\hline \multirow{4}{*}{$\begin{array}{l}\text { Lexical modal } \\
\text { auxiliaries }\end{array}$} & Has/have to & 1 & 2 & 2 & 6 & 0 & 0 & 11 & 1.2 \\
\hline \multirow{3}{*}{ Semi-modals } & Need to & 3 & 3 & 7 & 3 & 1 & 1 & 18 & 2.0 \\
\cline { 2 - 10 } & Dare & 0 & 0 & 0 & 0 & 0 & 0 & 0 & 0 \\
\hline
\end{tabular}




\begin{tabular}{|l|l|c|c|c|c|c|c|c|c|}
\hline \multicolumn{2}{|l|}{ Non-Auxiliary Modal Markers: } \\
\hline $\begin{array}{l}\text { Modal } \\
\text { adverbs }\end{array}$ & $\begin{array}{l}\text { e. g. certainly, } \\
\text { perhaps }\end{array}$ & 16 & 14 & 39 & 29 & 6 & 29 & 133 & 14.5 \\
\hline Modal adjectives & $\begin{array}{l}\text { e. g. apparent, } \\
\text { imperative }\end{array}$ & 7 & 7 & 9 & 17 & 0 & 7 & 47 & 5.1 \\
\hline $\begin{array}{l}\text { Modal lexical } \\
\text { verbs }\end{array}$ & $\begin{array}{l}\text { e. g. seems, } \\
\text { believe }\end{array}$ & 20 & 12 & 16 & 15 & 13 & 12 & 88 & 9.6 \\
\hline Modal nouns & $\begin{array}{l}\text { e. g. allegation, } \\
\text { a need }\end{array}$ & 6 & 0 & 8 & 9 & 3 & 6 & 32 & 3.5 \\
\hline Modal determiners & Pre & 10 & 13 & 6 & 17 & 7 & 11 & 64 & 7.0 \\
\cline { 2 - 48 } & Post & 0 & 1 & 0 & 5 & 0 & 1 & 7 & 0.8 \\
\hline Total & 132 & 113 & 215 & 203 & 103 & 150 & 916 & 100 \\
\hline
\end{tabular}

Table 1: Frequency of Occurrences of the Different Modal Markers Used across all the Editorials

\subsection{Ideological Implications of the Various Modal Auxiliaries as Used in the Editorials}

The editorials made use of both epistemic modal auxiliaries and deontic modal auxiliaries. While some of the occurrences of the epistemic modals were used to signal possibilities and probabilities (reflecting low convictions and weak authorial commitments to propositional contents), the majority of the occurrences of the modal auxiliaries were used to signal logical necessity and prediction, reflecting high editorial commitments to segments of the securityrelated discourse. Conversely, while only a few of the occurrences of the deontic modals were used to signal prohibitions and expectations (reflecting the newspapers' low involvement in some of the editorial contents), the majority of the occurrences of the modal auxiliaries were used to signal obligation and necessity (marking a high degree of editorial participation in the discourse and a strong reflection of editorial power and authority).

Must (not), should (not), and ought (not) to were classified as necessity modal auxiliaries. Although these three modals seem to have the same truth proposition, the latter, as used in the editorials, presented opinions more like subtle recommendations compared to the first two which explicitly expressed strong obligations or necessities. Ought to had only a total of $0.4 \%$ appearances across the sixty editorials because, unlike other necessity modals, it focused on past expectations and seemed to dwell on the past. An explanation for its minimal occurrence could be that it also signalled a low forcefulness based on the deontic scale and was not instrumental in pushing the editorials' intentions.

Ought to focused on what the newspapers expect key participants to have done or put in place in lessening previous incidents of security challenges in Nigeria as seen in MOD1-2 below.

MOD1: Unconventional war may be new to the country, but the intelligence apparatus ought to, by now, have overcome, initial setback and become proactive in operations to stave off senseless attacks on hapless Nigerians such as the one on the mosque [...] While the efforts of the Nigerian security forces in containing the insurgency in the northern part of the country are commendable, the security forces ought to assume more offensive posture in engaging the fundamentalist.

("The Terror Attack in Kano Mosque". The Guardian, 12.12.2014) 
MOD2: Wisdom ought to dictate that the authorities should discourage huge gatherings of people because they are primary targets of attacks by terrorists.

( "Checking Boko Haram's Renewed Offensive". The Sun, 20.07.2015)

MOD3: Farmers do not owe herdsmen a living and ought not to be expected to sacrifice their crops to feed the cows of the herdsmen.

("Time to Build Cattle Ranches". The Sun, 15.10.2015)

The modal auxiliaries in bold letters afforded Nigerian news organisations the opportunity to challenge the proactiveness of security operatives in the country towards decimating recurring security issues. Of the six newspapers chosen, only The Guardian and The Sun made choices of ought to, and these occurred in excerpts from editorials on Boko Haram's activities and herdsmen's attacks between 2014 and 2015. Ought to in MOD1 and MOD2 implicatively extend from the past to the present in that it has an added discursive function of advisability. Conversely, the modals were implicitly used to project the attitude of the media to the activities of anti-terrorism agencies towards insurgency in Nigeria. Since these security issues has lingered for a while in the country and the turn of events has probably been the same, the modal verbs are subtly used to portray the security operatives as lax, unperceptive towards the activities of Boko-Haram insurgents and violent herdsmen. The use of these modal auxiliaries is ideological in that they depicted failure and ineptness on the parts of the Nigerian intelligence agencies and security forces in inhibiting the myriads of insurgency in the Northern Nigeria. Thus, ought to was used to cast doubt on the efforts of the Nigerian security system in handling the Boko Haram sect and violent herdsmen. The Guardian exploited this modal auxiliary to deride the inert technique of the Nigerian security forces in battling insurgency in the north and to justify the loose procedure as the reason for the continuity of these nefarious activities in the northern region of Nigeria. Ideologically, the modal verb ought to is used to charge the security operatives to change their tactics and appropriate the right approach to curbing the menace.

In MOD3, the use of ought not to was The Sun's deontic approach to discredit a possible preexisting idea that the herdsmen's cattle are at liberty to graze on any farmland. Ideologically, the newspaper tilts towards a defence of the rights of the farmers and the safety of their crops. Thus, the farmers are projected as the victims in the attacks. The Sun's negative attitude towards the herdsmen is projected in the use of the modal auxiliary in this excerpt. The Sun maintained sympathy with the farmers by emphasising what should not be expected of them and deemphasising what measures farmers should have put in place.

Although ought to was minimally used across all the editorials because it seemed to dwell on the past, its minimal occurrences were still influential in leading readers into agreeing with the newspapers' views on security challenges in Nigeria. Ought not to", as used in the editorial, marked less forcefulness on the deontic scale of certainty. Other modal markers that helped to project the intentions of the newspapers were sufficiently employed. Must (not) and should (not) are markers of explicit obligations and had higher percentages of occurrence across the editorials. All the newspapers, except Vanguard, had should (not) as the modal auxiliary with the highest occurrence, which was closely followed by must (not). Bonyadi (2011: 1f.) asserts that editorials exploit the modality system to project favourable or unfavourable bias and reflect or obscure their projections in relation to their ideologies, as the case may be, in order to manipulate the minds of their readers. 
MOD4: The authorities must sensitise the nomads on the Pastoral Code and ensure that boundaries between pastoral lands and farmlands are clearly demarcated.

( "Killing in Defence of Cattle, Crops". Leadership, 29.01.2014)

MOD5: [...] the present militants must determine the real cost of their activities on their immediate environment and already beleaguered people on whose behalf they are supposedly undertaking their dangerous exertions.

("The FG/Niger Delta Militants Dialogue". The Sun, 04.09.2016)

MOD6: President Goodluck Jonathan himself being a "son of the soil" must publicly show interest in MEND's claims of the amnesty being another avenue for corrupt politicians to perfect their sleaze mentality.

("Niger Delta: Before another Assault". The Guardian, 30.05.2014)

MOD7: President Buhari must personally take control of the Niger Delta, home of the nation's economic mainstay, and make the region's rehabilitation a personal assignment [...] He must move nearer the people and personally assure them of his commitment against the background of distrust of past governments' intentions. The total liberation of the Niger Delta from poverty, unemployment, backwardness and illiteracy must be his priority.

("On the Niger Delta and Amnesty Programme". The Guardian, 11.08.2015)

MOD4-7 above depict the use of deontic modality by news agencies in Nigeria to influence the government and citizens to behave in certain ways that they consider would be beneficial to the peace and security of the nation. The auxiliaries were used to signal exigent, non-negotiable actions, indubitable measures or actions that should be embarked on if the lives and properties as well as the peace of the nation would be guaranteed. The excerpts are typical of the expression of deontic meanings by news organisations (who are considered advocates of the grassroot majority). The deontic modal must and its verbal collocates sensitise and ensure in MOD4 are used by Leadership to charge the Nigerian government to take drastic measures to disallow recurrent invasion of the herdsmen in order for peace to abide between herders and farmers who are both Agricultural land users. The editorial projected that an end to herdsmen attacks was only possible, if grazing reserves were mapped out and herdsmen were informed about existing grazing codes in the country. Implicitly, the modal auxiliary showed Leadership's positive disposition to the enactment of the National Grazing Bill under consideration in the National Assembly as a way out of the incessant spates of attacks. The use of must in MOD5-7 show the typical way that an influential person speaks to people over which it has influence. The excerpts are those on the Niger-Delta militancy in Nigeria. In MOD5, The Sun used must to implicitly perform a persuasive role on the Niger Delta militants and entreat them to reflect on the enormity of disaster facing the Niger Delta people and region as a result of their activities. The ideological function of this modal auxiliary is heightened with the postverbal nominals the real cost and beleaguered people. Although the newspaper represents the interest of the South-South people and what they stand for, its use of the modal auxiliary projected the newspaper's negative disposition to, and a detachment from, the activities of the Niger Delta militants. Thus, The Sun used must, on the one hand, to subtly inject a rethink into the minds of the militants while pushing, on the other hand, for an ultimate eradication of Niger Delta militancy.

MOD 6 and 7 mirrored the judgements and attitudes of The Guardian on the Jonathan and Buhari-led administrations towards militancy in the Niger Delta region. In MOD6, must as used 
presupposed that Goodluck Jonathan had been estranged from the concerns of the Movement for Emancipation of Niger Delta (MEND). MEND is an umbrella body of the Niger Delta militants and had repeatedly perceived the amnesty programme as a fraudulent means for corrupt politicians to syphon public funds into their private pockets. Must is ideological as its use was intended to impel President Jonathan to address the concerns of the Niger Delta militants and re-evaluate the essence of the amnesty programme in order to curb potential outburst of threats powered by the amnesty programme. In MOD7, The Guardian employed the repetitive instances of must to charge President Buhari to genuinely show interest in the welfare of the Niger Delta people. The newspaper positioned the Buhari administration as insensitive and depicted an apathetic attitude of the Buhari-led administration to the varying degrees of hardship by the Niger Delta people. In MOD7 and 8, The Guardian newspaper's use of the modal auxiliary depicted Presidents Jonathan and Buhari as merely paying lip service to the needs of the Niger Delta people and implicitly blamed the continuous rebellious attacks from this region on the negligence of both administrations.

The newspapers employed must to reflect editorial power by accentuating actions to be taken up by the Nigerian government. Must was also used in the editorials to dissuade militants from their various activities, project an insensitive image of the Nigerian government towards the Niger Delta people and finally challenge the Nigerian government to ensure it curbs insecurity in Nigeria.

The newspapers also employed the modal auxiliary should to portray certain ideological positions as in the examples below.

MOD8: Nigerians should change from apathy to continually living in painful remembrance of the girls, $[\ldots]$ the painful suspense of their condition should worry all; their unexplainable absence should trouble all, and the pain and unimaginable sorrow of their parents and family members should feel all with anguish. That the government and authorities are, as of yet, incapacitated and clueless about their state, should frighten all. And if the Nigerian government or any public official is privy to the situation of the Chibok girls and is keeping mum, Nigerians should feel betrayed and used by such. As a year ends today since the abduction, Nigerians should keep the Chibok Girls alive in their memories by insisting that the girls must be found and brought back home.

(“Chibok Girls: One year After". The Guardian, 14.04.2015)

MOD9: In Nigeria, the law should be reviewed and strengthened to make cattle rustling a serious crime punishable by severe penalties.

(“Arresting the Menace of Cattle Rustling". Daily Trust, 05.02.2014)

MOD10: The military should not be used in dealing with protests of this nature that do not portend danger $[\ldots]$ Government should also dialogue with the agitating groups with a view to addressing their grievances $[\ldots]$

("The Killing of the Pro-Biafra Agitator". The Sun, 08.06.2016)

In MOD8, the modal verb should is used seven times in the short text by The Guardian newspaper in admonishing Nigerians to take the issue of the abducted Chibok girls, still in custody, more seriously. Such usage of modals shows how power is subtly coded in the use of deontic modals by language users. The recurring instances of should were employed to perform multiple ideological functions. First, The Guardian employed the modal verb to provoke the 
reactions of Nigerians and control what their attitudes should be towards the abduction of the Chibok girls. Thus, the repeated occurrences of the modal verbs are influential to stirring the public to seek immediate release of the girls from the Nigerian government. The newspaper uses this to create an impression that the government is indifferent towards the release of the girls. The media employed structural parallelism should [...] all to stress how Nigerians should emotionally position themselves towards the release of the abducted Chibok girls. The frequent use of this parallel structure lent the newspaper's suggestions an autocratic tone and read more like a regulation than mere recommendations. The overriding intention was to create an unquenchable longing for the release of the abducted girls. In MOD9, Daily Trust's judgement on the Nigerian law was made explicit through the modal auxiliary should. Through the modal auxiliary, the Nigerian law is depicted as obsolete and in dire need for an imperative modification so as to be able to accommodate new trends of security challenges in Nigeria. Ideologically, the newspaper accuses the Nigerian governments of handling fresh security challenges with old tactics. In MOD10, should not was used to explicitly condemn the deployment of armed military personnel to peaceful protests, as is common in the Nigerian situation. The Sun implicitly marked the demonstrations of Pro-Biafra agitators as legitimate ways to express the minds of beleaguered Nigerians on issues that bother on their welfare. Thus, the newspaper upheld impishly the interests of the Biafra people and indirectly expressed support for their plights and protests. In addition, should was used in that same excerpt to signal the newspaper's attempt to prevent impending threats that may break out as a result of the ProBiafra agitators' perceived hatred for the south easterners and the undeserved killings of their colleagues by the Nigerian military. The print media projected the feeling that the Igbos may be forced to take laws into their own hands and attempt to avenge the deaths of their fellowagitators. The choice of should is thus informed by the print media's concern for potential crises. Should showed that Nigerian newspapers, even though they tried to project necessities, projected a median degree of epistemic commitment to their recommendations.

The modality markers would (not) were also employed to mark the attitudes of the newspapers to certain issues in the editorials analysed. It is important to note that all the lexical items highlighted in the excerpts are done by the author for empahsis and easy identification.

MOD11: Without doubt, such effort at community-level self-defence would raise awareness at grassroots that the continuous peace and safety of the community is the responsibility of everyone in the community.

(“The Kala/Balge Pushback against Insurgents". Daily Trust, 26.05.2014)

MOD12: Nobel laureate, Wole Soyinka, has put the task before the President in proper perspective. "I've yet to hear this government articulate a firm policy of non-tolerance for the serial massacres that have become the nation's identification stamp," Soyinka says. "The nation is treated to an eighteen-month optimistic plan which, to make matters worse, smacks of abject appeasement and encouragement of violence on innocents. I've yet to encounter a terse, rigorous, soldierly and uncompromising language from this leadership [...]." This resonates with Nigerians who desire that their President would behave like a true leader with a grasp of what to do.

("Treating Violent Herdsmen as Terrorists". The Punch, 06.05.2016)

The uses of the modal auxiliary would in the excerpts above relate the newspapers' biases and predictions towards certain recommendations and governmental attitudes. In MOD1 1 the modal 
auxiliary would foregrounded Daily Trust's positive disposition to community-level selfdefence, as a way to end Boko Haram insurgency. The newspaper's choice of a positive high degree predictive modal auxiliary of this nature attributed such an act to mere push-back, selfconsciousness and self-protective measure against insurgency. The print media's positive affirmation of the result of community-level self-defence through the modal would encouraged grass-root violence in Kala/Balge communities and the entire northern region. Daily Trust's disposition is a spite on the Nigerian security force, who are generally assumed to be lethargic towards the warnings of impending attacks, and reflects the newspaper's clear and firm consideration of self-defence as apposite to awakening self-consciousness and sensitisation in the troubled communities. Would in MOD12 projects The Punch's non-perception of Buhari as "a true leader" or as someone capable of managing Nigeria's peculiar security challenges. Being a newspaper situated in south-west Nigeria, the newspaper's choice of the modal auxiliary depicts the president as one who shares some tribal sentiments with the herders and deficient of a clear and objective decision on the farmers-herders' crises in the country. The modal auxiliary thus expresses The Punch's negative disposition towards the Buhari-led administration and projects it as an insensitive government especially in relation to the spates of herdsmen attacks. The Punch thus portrayed Buhari as lacking the qualities of a true leader, among which empathy is.

The modality markers can (not) and could were also employed to mark the attitudes of the newspapers to certain issues in the editorials analysed.

MOD13: We cannot bring terrorists to account when we place personal and political considerations above millions of lives at risk. The lives at risk could be anyone's as the indiscriminate attacks have proved. The war against terrorists can be won when we are pulling together.

("Nothing Shocks Again". Vanguard, 30.06.2014)

MOD14: Nigeria can learn a lot from Special Forces in the West with many success stories in anti-terrorism operations, which include the US Navy SEAL, Israel's Sayeret MATKAL, and the United Kingdom's Special Air Service.

("Imperative of an Anti-Terrorism Task Force". The Punch, 30.08.2015)

The negative modal cannot was used in MOD13 to condemn the slackness of the government to insurgency and to categorically state the difficulty the Nigerian government would face in bringing Boko Haram insurgents to book if it is not ridden of personal and political aggrandisement. At the time this editorial was written, much attention was placed on jingles on who becomes the next president of the Federal Republic of Nigeria in 2015 to the neglect of issues on national security. In the excerpt, Vanguard also used could to push the possibility of any Nigerian losing his/her life to the Boko Haram group, irrespective of status.

The overriding intention here was to project the feeling of lack of security and restiveness in Nigerians and push the seeming unconcerned government to action in eliminating the Boko Haram insurgents once and for all. Can was implicitly used to consciously draw in all Nigerians in the fight against the Boko Haram sect. Can, though ranking lowest on the epistemic modality scale, was instrumental in projecting guaranteed victory over the sect if every Nigerian joins in the fight. In MOD14, can was used to project The Punch's positive disposition to an auspicious result of the incorporation of Foreign Special Forces in the fight 
against Boko Haram based on past successes in handling similar situations. The modal auxiliary, on the one hand, mirrored the media's positive disposition towards the involvement of these special forces and, on the other hand, disparaged the efforts of the Nigerian security forces over the insurgents.

\subsection{Ideological Implications of the Non-Auxiliary Modal Markers as Used in the Editorials}

All the newspaper editorials analysed calculated the degree of commitment accrued to their propositions based on the extent of precision and reliability that was at their disposal as seen in the excerpts below.

MOD15 The stealing of cattle has evolved over the years into a dangerous and sometimes bloody activity in Nigeria.

(“Arresting the Menace of Cattle Rustling”. Daily Trust, 05.02.2014

MOD16: Perhaps, for the first time since Muhammadu Buhari assumed power nine months ago, a senior official of the Federal Government has come out to promise action against the threat posed by the so-called "Fulani Herdsmen" [...]

(“Danbazzau's Pledge to Tackle Herdsmen's Menace". Vanguard, 02.03.2016)

MOD17: Col. Usman Kukasheka has explained, the operations are still on to capture Point Zero. It is probably after achieving this that we can recover the rest of the abducted girls and apprehend the leadership of the insurgents such as Abubakar Shekau and Abu Musab Al Barnawi.

("Caution after the Fall of Sambisa Forest". Vanguard, 28.12.2016)

MOD18: The agitators, made up of members of the Indigenous People of Biafra (IPOB), Movement for the Actualisation of the Sovereign State of Biafra (MASSOB) and Biafra Independence Movement (BIM), were reportedly killed at various locations in Onitsha during the celebration of the 49th anniversary of the declaration of Republic of Biafra on May 30 [...] Two policemen were reportedly killed during the May 30 protests while some soldiers were also wounded.

("The Killing of the Pro-Biafra Agitators". The Sun, 08.06.2016)

MOD19: Tiv youths had allegedly killed about 30 cows belonging to some herdsmen that destroyed their farmlands.

(“Killing in Defence of Cattle, Crops". Leadership, 29.01.2014

In the editorials, modal adverbs were used to signal circumventing expressions. They were employed to function as protective comments in case their speculations were faulted. Because editorials are widely-read columns of the newspaper and the newspapers' claims and stance on prominent national issues are usually evaluated through a prism of generally known facts, modal adverbs such as sometimes, perhaps and probably were used to lessen the degree of conviction in those claims. In MOD18 and MOD19, the newspapers withheld full commitments to the activities of certain participants in security-focused incidents. The newspapers adopted the modal adverbs reportedly and allegedly in the excerpts so that the information will be interpreted as speculations rather than accredited facts. The print media are aware that misinformation in this sensitive narrations may engender other security issues. Also, editors are not usually present at the scene of events but largely rely on what they are fed with in news reports and thus claim-making may be risky. The use of these modal adverbs is motivated by 
the desire to maintain a positive face, or rather, the newspaper's appeal for sympathy from the readers in case any imprecision is discovered. The excerpts showed that both newspapers approached the security issues that emanated from their regions objectively in that they were honest in relating the issues in their regions based on the extent of the knowledge they have. There were no exaggerations in the ways they portrayed the issues.

In the development of arguments, an editorial is supposed to succinctly present facts in a logical manner in such a way that its importance can easily be deduced by the readers (Daramola 1999). Since writings on security challenges seem to keep readers at the edges of their chairs, modal adjectives were used as a means of presenting the truthfulness that certain statements are laced with.

In MOD20, The Punch's adopts the modal adjective to project the Nigerian government as untruthful in its handling of Boko-Haram insurgents. The newspaper presumed that the release of the abducted Chibok girls may have been facilitated with a monetary exchange between the federal government and the insurgents. Ideologically, the newspaper projects the Nigerian government as culpable of aiding the Boko-Haram sect to thrive in their nefarious activities.

MOD21: Especially in the South-west, where the crime has shifted to, there is the need to come out with special squads to track down kidnappers.

(“Kidnapping: Need for Fresh Approach”. The Punch, 02.10.2015)

MOD22: The foregoing points to the need for a new approach to the Niger Delta issue if the region and the country shall enjoy lasting peace.

(“On Niger Delta Avengers". Daily Trust, 25.05.2016)

MOD23: The recent announcement that the Federal Government is handling this issue silently does not address the magnitude and urgency of this problem.

("The Killing of the Pro-Biafra Agitator". The Sun, 08.06.2016)

The modal noun phrases the need in MOD21 and MOD22 were borne out of the newspapers' concern for the countless cases of kidnappings and militancy in Nigeria. The modal nouns were deliberately employed in order to heighten a feeling of imperativeness and necessity for these recommendations to be welcomed and carried out. Consequently, it is a call on the government to act fast on the group because their existences may lead to the sprouting of newer militant groups in other parts of the country.

In MOD23, the modal noun phrases the magnitude and urgency were used to portray the killings of Pro-Biafra agitators in Nigeria as a gigantic problem which if not dealt with could crumble the nation. The Sun newspaper seems to share regional affiliation with the pro-Biafran agitators as the newspaper employed the modal noun phrases the magnitude and urgency to heighten the impression of more weighty problems if something is not done about those who killed the south easterners.

\section{Conclusion}

This study has attempted an analysis of modality on editorials on security challenges in Nigeria and how the linguistic manifestations of modal markers were used to project the media's stance on various security challenges bedevilling the nation. The analysis of modality revealed that the six newspapers expressed unbiased concerns over the Boko-Haram Insurgency whether or 
not the newspaper is situated in the northern region. The modality was not used by any of the news organisations to obscure security problems emanating from particular regions. However, some of the newspapers projected some forms of sentiments to some regional security issues. The fact that certain security issues emanated from particular regions also prompted the kinds of modal markers employed by specific newspapers representing such regions. The Sun's choices of modal verbs on the pro-Biafra agitators upheld impishly the interests of the Biafra people and indirectly expressed support for their plights and protests. The Punch's choices of modal verbs portrayed President Buhari as sharing some ethnic sentiment with herders which is responsible for their repeated attacks. The choices of the modal verbs by the six newspapers justify the negligence of the Niger-Delta people as responsible for militancy in the Niger-Delta region.

\section{References}

Aboh, Romanus (2012): "Modality as a discourse strategy in new Nigerian poetry". Journal of Nigerian Studies 1/2: 1-18.

Bonyadi, Alireza (2011): Linguistic manifestations of modality in newspaper editorials. International Journal of Linguistics 3/1: 1-13.

Boicu, Ruxandra (2007): "Modal verbs and politeness strategies in political discourse". Seminar Paper Presented at the University of Bucharest, Faculty of Journalism and Communication Studies.

Daramola, Ifedayo (1999): Laws and Ethics of Media Practice. Lagos: Rothan Press.

Djadi, Illa (2016): “UPDATE: Hundreds killed in Nigeria attacks". worldwatchmonitor.org/2016/03/update-hundreds-killed-in-Nigeria-attacks [10.03.201].

Downing, Angela/Locke, Philip (2006): English grammar - A university course. New York: Routledge.

Ebienfa, Kimiebi (2011): "Militancy in the Delta and the Emergent Categories". Review of African Political Economy 38/130: 637-643.

Fowler, Roger (1986): Linguistic criticism. Oxford: Oxford University Press.

Gabrielatos, Costas/Mcenery, Tony (2005): "Epistemic modality in M. A. dissertations". In: Fuertes Olivera, Pedro (ed.): Lenguay Sociedad: Investigaciones recientes en lingüística aplicada. Valladolid, Universidad de Valladolid: 311-331. (=Lingüística Filología 61).

Halliday, Michael (1970): "Functional diversity in language as seen from a consideration of modality and mood in English". Functions of Language 6: 322-361.

Halliday, Michael/Mathiessen, Christian (2014): Halliday's introduction to functional grammar. New York: Routledge.

Hyland, Ken (2005): Metadiscourse: Exploring interaction in writing. London/New York: Continuum.

Khalid, Parwez (2013): "Modality analysis of the newspaper articles about the Scottish Ship RMS Queen Elisabeth”. Academic Journal of Interdisciplinary Studies 2/1: 458-461.

Lillian, Donna (2008): "Modality, persuasion and manipulation in Canadian conservative discourse". Critical Approaches to Discourse Analysis Across Disciplines 2/1: 1-16.

McCabe, Anne/Heilman, Karl (2007): “Textual and Interpersonal Differences between a News Report and an Editorial”. Revista Alicantina de Estudios Ingleses 20: 13-156. 
Ogunwale, Timothy (2008): Advanced Editorial Writing and Specialized Reporting. Oyo State, Nigeria: Penmen's Press Services Agency.

Olaniyan, Kazeem/Adeniji, Adeolu (2015): "Modality in statement of objectives in arts-based research abstracts". British Journal of English Linguistics 3/1: 42-51..

Palmer, Frank (1986): Mood and modality. Cambridge: Cambridge University Press

Palmer, Frank (2003): "Modality in English: Theoretical, descriptive, and typological issues". In: Facchinetti, Roberta/Krug, Manfred/Palmer, Frank, (eds.): Modality in contemporary English. Berlin/New York, Mouton de Gruyter: 1-17.

Puteri, Zarina (2013): "Modality analysis of the newspaper articles about the Scottish Ship RMS Queen”. Academic Journal of Interdisciplinary Studies 2/9: 458.

Qun, Zheng (2010): Modality and generic features in Chinese EFL writing. Chinese Journal of Applied Linguistics 33: 40-51.

Someya, Yasumasa (2010): "Modal Verbs and their Semantic Functions in Business English". Aoyama journal of business 3/44: 1-37.

Sweetser, Eve (1990): From etymology to pragmatics. Cambridge: Cambridge University Press.

Vanguard (2016): Vanguard Media Limited 26.04.2016. vanguardngr.com/2016/04/bloodbathenugu-fulani-herdsmen-kill-40 [11.03.2012].

Vazquez, Ignacio/Giner, Diana (2008): "Beyond mood and modality: epistemic modality markers as hedges in research articles: a cross disciplinary study". Revista Alicantina de Estudios Ingleses 21: 171-190.

Vold, Eva (2006): "Epistemic modality markers in research articles: a cross-linguistic and cross-disciplinary study”. International Journal of Applied Linguistics 16/1: 61-87.

Wang, Junling (2010): “A critical discourse analysis of Barack Obama's speeches”. Journal of Language Teaching and Research 1/3: 254-261. 